\title{
Putative non-stereo specific dehalogenase from Antarctic of Psychotropic Bacillus sp. IH01
}

\author{
Ismail Haruna ${ }^{1}$, Hassana Abubakar ${ }^{2}$, Roswanira Ab. Wahab ${ }^{3}$, Fahrul Huyop ${ }^{4}$ \\ 1,2,4Biosciences Department, Faculty of Science, Universiti Teknologi Malaysia, 81310 UTM Johor Bahru, Johor, \\ Malaysia. \\ ${ }^{1,2}$ Department of Microbiology, Bauchi State University Gadau, PMB 65 Gadau Bauchi State, Nigeria. \\ ${ }_{2}^{2}$ Department of Biochemistry, Ibrahim Badamasi Babangida University Lapai, PMB 11 Niger State, Nigeria. \\ ${ }^{3}$ Chemistry Department, Faculty of Science, Universiti Teknologi Malaysia, 81310 UTM Johor Bahru, Johor, Malaysia. \\ ${ }^{4}$ Corresponding email: fahrul@utm.my
}

\begin{abstract}
The main aim of the study was to isolate and identify any organism that can degrade 2,2dichloropropionic acids (2,2DCP) from Antarctica soil and water environment. Antarctica is well known of its extreme cold temperature. In this study we successfully isolated at least six colonies (AA1, AA2, AB1, $\mathrm{AB} 2, \mathrm{AC} 1$ and $\mathrm{AC} 2$ ) from Antarctic environment of the soil sample grown on Antarctic Bacterial Medium. Of the six isolates, only isolate AA2 was could grow on a minimal media containing 2,2-dichloropropionic acids as a sole source of carbon. Analysis of the 16S rRNA gene sequence and biochemical tests, identified strain AA2 belongs to Bacillus sp.. The bacterium showed slow growth below $5^{\circ} \mathrm{C}$, with cells doubling time of 32 hours. The chloride ion released was $0.657 \mathrm{mmolCl} / \mathrm{L}$ on $20 \mathrm{mM}$ of 2, 2-DCP. In conclusion current study is important to explore biotechnological applications of cold adapted organisms and its special properties for fundamental applications. The new isolate can be used to improve the present bioremediation methods at low temperature. This is the first reported case about microbial growth on 2,2DCP (DALAPON) using a bacteria isolated from Antarctica.
\end{abstract}

Keywords: Antarctic Bacterial Medium (ABM); 2,2-dichloropropionic acid (2,2-DCP), Dehalogenase; Biodegradation.

\section{Introduction}

The chemically synthesized herbicides application in agricultural areas and industries have recorded remarkable successes by increasing products yield (Fetzner and Lingens, 1994), but at the same time is of serious concern to the public. These recalcitrant pollutants cause environmental pollution of underground water and rivers. Studies have also shown that these compounds can be carcinogenic to both human and animals (Zulkifly et al., 2010). These halogenated xenobiotic compounds are converted to harmless form using the ubiquitous degradation ability of microorganism or by employing non biological method, the former is preferable because is safer, more economical, and environmental friendly (Haritash and Kaushik, 2009). Various microorganisms can degrade halogenated compounds and utilize it as a carbon source therefore, play an important role in dehalogenation. These organisms achieved this by secreting an inducible enzyme which cleaved their carbon halogen bonds (Janssen et al., 1994). These group of enzymes are called dehalogenases. Considering the advantages biological methods over non biological methods in remediation of halogenated polluted sites (safer, cheaper, and environmental friendly), the search for dehalogenase producing organisms has increased.

Despite previous report that organisms from cold adapted environments are naturally pre-exposed to halogenated compounds (Gribble, 1996), where, most dehalogenases reported are from terrestrial and very rare from organisms inhabiting the Arctic and Antarctic regions because most studies of bacteria in Arctic environmental samples focused more on their diversity. Therefore, there is a need to find cold adapted bacteria that has dehalogenases that is widely distributed in natural environment and adapt more to widerange of temperature (Radjasa et al., 2001). This research will make a significant contribution to the existing knowledge of bioremediation especially that of degradation of halogenated compounds and also to the existing knowledge of bacterial diversity in Polar Regions. 


\section{Materials and Methods Sample collection}

The soil was previously collected from arctic region around Svalbard Ireland (Latitude $77^{\circ} \mathrm{N}$, Longitude $\left.15^{\circ} \mathrm{E}\right)$. The sample was successfully taken to the laboratory under strict sterile conditions.

\section{Isolation and identification of organisms}

An approximately, $2 \mathrm{~g}$ of soil sample was mixed in $10 \mathrm{ml}$ sterile distilled water. The solution was then spread on Antarctic Bacterial Medium (ABM) (peptone 5g/l, yeast extract $2 \mathrm{~g} / \mathrm{l}$ and agar 20g/l (Srinivas et al., 2009). Streak plate method was used to inoculate the bacteria that grown on ABM on a solid minimal media supplemented filtered 2, 2, DCP (Jing et al., 2005). The liquid minimal media was prepared as $10 \mathrm{x}$ concentrated basal salt containing K2HPO4.3H2O (42.5 g/l), (NH4)2SO4 (25g/l) and NaH2PO4. 2H2O $(10.0 \mathrm{~g} / \mathrm{l})$. The trace metal salts solution was a $10 \mathrm{x}$ concentrate that contained nitroloacetic acid (1.0 g/l), MgSO4 (2.0 g/l), FeSO4.7H2O $(120.0 \mathrm{mg} / \mathrm{l}), \mathrm{MnSO} 4.4 \mathrm{H} 2 \mathrm{O}(30.0 \mathrm{mg} / \mathrm{l})$, $\mathrm{ZnSO} 4 . \mathrm{H} 2 \mathrm{O}(30 \mathrm{mg} / \mathrm{l})$ and $\mathrm{CoCl} 2(10.0 \mathrm{mg} / \mathrm{l})$ in distilled water (Hareland et al., 1975). Minimal media for growing bacteria contained $10 \mathrm{ml}$ of $10 \mathrm{x}$ basal salts and $10 \mathrm{ml}$ of $10 \mathrm{x}$ trace metal salts per $100 \mathrm{ml}$ of distilled water and were autoclaved $\left(121^{\circ} \mathrm{C}\right.$ for $\left.15 \mathrm{~min}\right)$. The carbon source, 2,2-DCP was neutralised with $\mathrm{NaOH}$ and sterilised by filtration and added to the autoclaved salt medium to a final concentration of $20 \mathrm{mM}$. The bacteria characteristics were identified using a standard microbiological Gram staining method and 16S rRNA gene sequencing. Other biochemical characterization of the isolate was carried out using standard procedures (Cappuccino and Sherman, 2002). The polymerase chain reaction (PCR) was carried out using standard 16S rRNA gene universal primers, $27 \mathrm{~F}$

$(5$ AGAGTTTGATCCTGGCTCAG 3') and 1492R (5' CGGTTACCTTGTTACGACTT $\left.3^{\prime}\right)$. The amplification reactions contained in $50 \mu \mathrm{l}$ with $300 \mathrm{ng}$ template DNA, $20 \mathrm{pmol}$ forward primer (27F), 20 pmol of reverse primer (1429R), 25ul (2x) PCR cycle was set as: initial denaturation $94^{\circ} \mathrm{C}$ for $5 \mathrm{~min}$, followed by cooling, denaturation $94^{\circ} \mathrm{C}$, annealing, $55^{\circ} \mathrm{C}$ for $1 \mathrm{~min}$; extention, $74^{\circ} \mathrm{C}$ for $4 \mathrm{~min}$ and final extention, $74^{\circ} \mathrm{C}$ for $10 \mathrm{~min}$. The PCR product was electrophoresed on a
$0.8 \%$ agarose gel. For sequencing reaction, the PCR product was purified with PROMEGA (USA) product purification kit prior sending for sequencing (1st Base Laboratory, Biosyntech, Selangor). The sequences were compared to the sequence in the public data bases using BLAST search program on the National Centre for biotechnology information (NCBI) website (http://www.ncbi.nlm.nih.gov/)

\section{Growth conditions: Growth Profile of Isolated Bacteria}

The bacterial growth profile was obtained by measuring the bacterial growth in different concentration of 2,2-DCP. The isolated bacterium was grown in a liquid minimal media at $30^{\circ} \mathrm{C}$ in shaker incubator, rotating at $200 \mathrm{rpm}$. Four different concentrations 10 $\mathrm{mM}, 20 \mathrm{mM}, 30 \mathrm{mM}$ and $40 \mathrm{mM}$ of 2,2-DCP was used as a carbon source. The growth of the bacteria was measured under the absorbance A680nm every 4 hours' interval.

\section{Chemicals}

All chemicals were obtained from sigma Aldrich chemical company (USA); 2, 2, dichloropropionic acid.

\section{Results and discussion}

Six bacteria were isolated from soil on Antarctic bacterial medium. They were labelled AA1, AA2, AB1, AB2, AC1 and $\mathrm{AC} 2$. Out of the six isolates, only isolate $\mathrm{AA} 2$ was found to grow on 2,2-DCP. Halogenated compounds are toxic to the cells, only few organisms are able to utilize it as sole carbon source. Isolate AA2 grown on 2,2-DCP indicates the presence of dehalogenase producing genes. The number of colonies obtained on ABM was higher when compared to plate with 2,2-DCP. The bacterial colony was observed as smooth surface and formed milky colonies on ABM and 2, 2, DCP containing medium. No growth was observed when isolate AA2 was incubated on another type of minimal media in which 2,2-DCP was replaced with monochloroacetate (MCA) as a carbon source. AA2 was found to be Grampositive bacteria. The bacterium was motile and demonstrated its ability to utilize oxidase, starch, catalase, citrate, nitrate, gelatin liquefaction. However, the isolate is indole and urease negative. The overall biochemical tests were matched to the genus Bacillus sp. as indicated in Bergey's Manual of Systematic 
Bacteriology (Holt et al., 1994). Partial 16S rRNA gene sequencing also matched to the sequence belongs to Bacillus sp., therefore AA2 was designated as Bacillus sp. strain IH01. The 16S rRNA partial gene sequence of the dehalogenase producing isolate was successfully deposited in GenBank nucleotide database with Gene Bank Accession Number KX000297 under strain Bacillus sp. IH01. Figure 1.1 shows the result of the bacterial growth in each concentration. The best 2,2DCP concentrations suitable for the growth of the bacterium was at $20 \mathrm{mM}$ with doubling time of 32 hours.

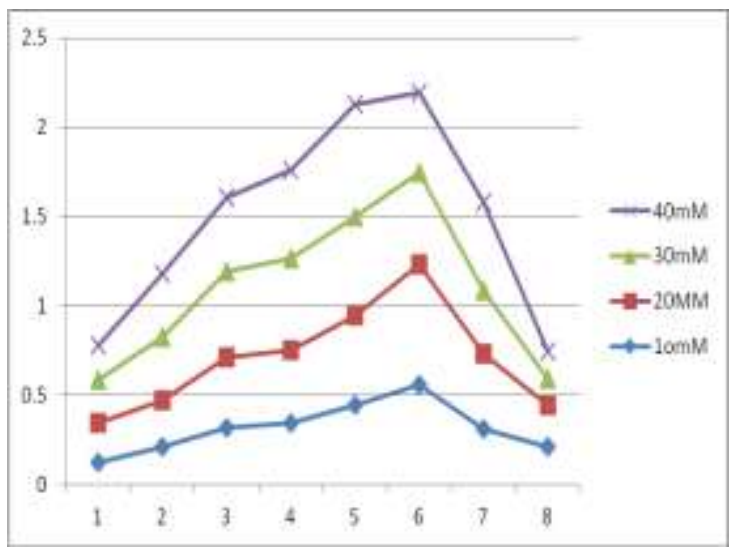

Figure 1. Growth profile of the Bacillus sp. IH01 in different concentrations of 2,2DCP. The doubling time of the bacteria grown in $20 \mathrm{mM} 2,2 \mathrm{DCP}$ as a carbon source was estimated to be 32 hours.

Release of halogen ion is an indicator that the bacteria can degrade halogenated compound and released chloride. The isolated bacteria were found to release chloride ion and maximum release of the chloride ion assay for the isolated bacteria was $0.675 \mathrm{mmol} / \mathrm{L}$ in the presence of $20 \mathrm{mM}$ 2,2-DCP. The release of chloride ion suggests that bacteria is capable of degrading 22-DCP and utilize it as a sole carbon source and energy by the putative dehalogenase enzymes and release chloride ion as the final product. A phylogenetic tree was constructed suggest that the strain belongs to Bacillus sp.

\section{Conclusion}

Environmental biotechnology is attracting more attention especially in the area of bioremediation of pollutants. This is because it is widely accepted by the public and is considerably cheap. Studies have shown that increasing human activities in the polar regions by tourist and scientist have resulted in deposition of halogenated compounds in these areas. Microorganisms that can degrade halogenated compounds produce the enzymes dehalogenases which breaks the carbon halogen bond of the compound. We have discovered strain IH01 grew for the first time in 2,2-DCP suggesting its cold adapted ability to degrade halogenated toxic compounds. To the best of our knowledge, this is the first time we are reporting degradation of 2,2-DCP by psychotropic Antarctic bacteria.

\section{Refrences}

Bergmann, J. and Sanik Jr, J. (1957). Determination of trace amounts of chlorine in naphtha. Analytical Chemistry. 29(2), 241-243.

Cappuccino, J. and Sherman, N. (2002). Microbiol. a laboratory manual. Pearson Education, Inc. San Francisco, CA.

Fetzner, S. and Lingens, F. (1994). Bacterial dehalogenases: biochemistry, genetics, and biotechnological applications. Microbiological Reviews. 58(4), 641685.

Gornall, A. G., Bardawill, C. J. and David, M. M. (1949). Determination of serum proteins by means of the biuret reaction. J. biol. Chem. 177(2), 751766.

Gribble, G. (1996). Naturally Occuring Organohalogen Compounds-A Comprehensive Survery. Springer.

Hareland, W. A., Crawford, R. L., Chapman, P. J. and Dagley, S. (1975). Metabolic function and properties of 4hydroxyphenylacetic acid 1hydroxylase from Pseudomonas acidovorans. Journal of Bacteriology. 121(1), 272-285.

Haritash, A. and Kaushik, C. (2009). Biodegradation aspects of polycyclic aromatic hydrocarbons (PAHs): a review. Journal of hazardous materials. 169(1), 1-15.

Holt, J., Krieg, N., Sneath, P., Staley, J. and Williams, S. (1994). Bergey's manual of determinative microbiology. Williams and Wilkins, Maryland.

Janssen, D. B., Pries, F. and Van der Ploeg, J. R. (1994). Genetics and biochemistry 
of dehalogenating enzymes. Annual Reviews in Microbiology. 48(1), 163191.

Jing, N. H., Wahab, A., Cooper, R. and Huyop, F. (2005). Degradation of Herbicide (3-Chloropropionic Acid) By Bacterial Dehalogenases. Proceedings of KUSTEM 4th Annual SeminarKuala Terengganu Malaysia2-5 May. 586590.

Radjasa, O. K., Urakawa, H., Kita-Tsukamoto, K. and Ohwada, K. (2001). Characterization of psychrotrophic bacteria in the surface and deep-sea waters from the northwestern Pacific Ocean based on $16 \mathrm{~S}$ ribosomal DNA analysis. Marine Biotechnology. 3(5), 454-462.
Srinivas, T., Rao, S. N., Reddy, P. V. V., Pratibha, M., Sailaja, B., Kavya, B., Kishore, K. H., Begum, Z., Singh, S. and Shivaji, S. (2009). Bacterial diversity and bioprospecting for coldactive lipases, amylases and proteases, from culturable bacteria of Kongsfjorden and Ny-Ålesund, Svalbard, Arctic. Current microbiology. 59(5), 537-547.

Zulkifly, A. H., Roslan, D., Hamid, A., Hamdan, S. and Huyop, F. (2010). Biodegradation of low concentration of monochloroacetic acid-degrading Bacillus sp. TW1 isolated from terengganu water treatment and distribution plant. Journal of Applied Sciences. 10(22), 2940-2944. 